\title{
GAMBARAN KEJADIAN KARIES GIGI PADA ANAK KELAS 2 SEKOLAH DASAR NEGERI 20 SUNGAISELAN
}

\section{DESCRIPTION OF DENTAL CARIES IN SECOND CLASS STUDENTS OF PUBLIC ELEMENTARY SCHOOL 20 SUNGAISELAN}

\author{
Angga Prawira Kusuma 1), Abdul Muhaimin Taiyeb ${ }^{2)}$ \\ 1)Staf UPTD Puskesmas Lampur Kab. Bangka Tengah \\ 2) Widyaiswara BBPK Makassar
}

e-mail :anggaprawirakusuma07@gmail.com

\begin{abstract}
Dental and oral health problems are a disease that affects nearly half of the world's population. The prevalence of dental caries in Indonesia tends to be high above $70 \%$. The aim of this study was to describe the incidence of dental caries in Publik Elementary School 20 Sungaiselan and the factors associated with the incidence of dental caries. The research methodology used descriptive qualitative and analyzed using the Chi Square method. The results showed that $54.17 \%$ of the respondents were male, $70.83 \%$ of students consumed high levels of cariogenic food and $66.67 \%$ brushed their teeth more than twice a day. From this study, it was known that gender had no significant effect $p=0.446$, however the level of cariogenic food consumption and the frequency of brushing teeth had a significant effect on $p=0.001$ and $p=0.002$ at the $5 \%$ level.
\end{abstract}

keywords: caries, cariogenic, teeth

\section{ABSTRAK}

Masalah kesehatan gigi dan mulut merupakan penyakit yang hampir dialami oleh setengah populasi di dunia. Prevalensi karies gigi di Indonesia cenderung tinggi di atas 70\%.Tujuan dari penelitian ini untuk mengetahui gambaran kejadian karies gigi di SD Negeri 20 Sungaiselan dan faktor yang berhubungan dengan kejadian karies gigi. Metodelogi penelitian menggunakan deskriptif kulitatif dan dianalisis dengan menggunakan metode Chi Square. Hasil penelitian menunjukkan bahwa 54,17 \% responden berjenis kelamin laki-laki, 70,83\% siswa mengkonsumsi makanan kariogenik dengan tingkat tinggi serta 66,67\% melakukan sikat gigi lebih dari dua kali sehari. Dari penelitian ini diketahui bahwa jenis kelamin tidak memiliki pengaruh yang signifikan $p=0,446$, namun tingkat konsumsi makanan kariogenik dan frekuensi menyikat gigi memiliki pengaruh yang signifikan $p=0,001$ dan $p=0,002$ pada taraf $0,05 \%$.

Kata Kunci : karies, kariogenik, gigi

\section{Pendahuluan}

Masalah kesehatan gigi dan mulut merupakan penyakit yang hampir dialami oleh setengah populasi di dunia (3,56 Miliar jiwa). Penyakit pada gusi merupakan penyakit nomor 11 paling banyak terjadi di dunia. Selain itu di asia pasifik penyakit kangker mulut menempati urutan ke tiga jenis kanker paling banyak di derita (Kemenkes 2019)

Prevalensi penyakit karies gigi di Indonesia cenderung meningkat. Data dari Departemen Kesehatan Indonesia menunjukkan $42,8 \%$ penduduk menderita penyakit periodental dan $63 \%$ penduduk Indonesia menderita karies gigi aktif yang belum ditangani, namun untuk beberapa provinsi angka tersebut lebih tinggi dari angka nasional, seperti di Kalimantan $80,2 \%$, Sumatera $65,4 \%$, sedangkan yang terendah adalah Jawa dan Bali yaitu $56,8 \%$ (Depkes RI, 2000).

Menurut Pusdatin Kemenkes (2018), prevalensi karies gigi di Indonesia adalah
$88,8 \%$ dengan prevalensi karies akar adalah $56,6 \%$. Prevalensi karies gigi cenderung tinggi (di atas $70 \%$ ) pada semua kelompok umur. Anak-anak yang berada pada usia 59 tahun memiliki angka prevalensi sebesar $92,6 \%$.

Hasil studi morbiditas SKRT (Survei Kesehatan Rumah Tangga) dalam Surkenas (Survei Kesehatan Nasional) 2001 menunjukkan bahwa dari 10 kelompok penyakit terbanyak yang dikeluhkan masyarakat, penyakit gigi dan mulut menduduki urutan pertama (60\%). Hasil studi SKRT 2001, menyatakan bahwa $52,3 \%$ usia sekolah dasar mengalami karies gigi yang belum ditangani. Prevalensi karies usia 10 tahun pada anak sekolah adalah sakit gigi urutan pertama keluhan masyarakat. Berdasarkan SKRT 2004, karies sendiri merupakan masalah dalam kesehatan gigi dan mulut di Indonesia dengan prevalensi $90.05 \%$.

Berdasarkan Badan Penelitian dan Pengembangan Kesehatan (2007) 
sebanyak $86,8 \%$ penduduk yang berusia di atas 12 tahun di Provinsi Kepulauan Bangka Belitung pernah mengalami karies gigi, sementara $50,8 \%$ belum pernah melakukan perawatan. Di kabupaten Bangka tengah, karies gigi menempati urutan ke enam (2616 kejadian) dari 20 penyakit terbanyak (Dinas Kesehatan Kabupaten Bangka Tengah 2014). Berdasarkan hasil laporan kegiatan UKGS di wilayah kerja Puskesmas Lampur, diketahui masih tingginya angka karies gigi pada anak SD. Dari 10 SD yang ada di wilayah kerja Puskesmas Lampur, bahwa rata-rata angka karies gigi pada anak SD melebihi angka nasional. Pada tahun 2018 angka karies gigi sebesar 51,4\%, sedangkan pada tahun 2019 mengalami peningkatan yaitu sebesar 54,14\%. (Puskesmas Lampur, 2019).

Karies adalah kerusakan yang terbatas pada jaringan gigi mulai dari email gigi hingga menjalar ke dentin (tulang gigi). Penyebab karies adalah adanya bakteri Streptococcusmutans dan lactobacili. Faktor-faktor yang menyebabkan karies gigi adalah permukaan gigi, bakterikariogenik (penyebab karies), karbohidrat yang difermentasikan, waktu dan tingkat kebersihan mulut. Faktor luar antara lain adalah usia, jenis kelamin, keadaan penduduk, lingkungan, pengetahuan, kesadaran dan perilaku yang berhubungan dengan kesehatan gigi, misalnya pengetahuan mengenai jenis makanan dan minuman yang menyebabkan timbulnya karies gigi pada anak-anak tersebut (Maulani, 2005). Sebagian besar anak-anak sangat suka mengkonsumsi makananmakanan kariogenik karena rasanya manis, lengket serta warna yang menarik, Padahal terlalu sering mengkonsumsi makanan kariogenik akan memicu terbentuknya karies gigi. Selain itu, anak-anak sering lalai dalam membersihkan gigi karena kurangnya motivasi dan kurangnya kesadaran untuk menjaga kesehatan gigi.

SD N 20 Sungaiselan merupakan salah satu sekolah dasar yang termasuk kedalam wilayah kerja Puskesmas Lampur Kabupaten Bangka tengah. Studi awal yang telah dilakukan pada tahun 2019, diketahui bahwa lebih dari $61,14 \%$ siswa SD N 20 Sungaiselan mengalami karies gigi. Hal ini perlu mendapat perhatian lebih dari tenaga kesehatan, Berdasarkan uraian di atas maka perlu dilakukan penelitian mengenai gambaran karies gigi di SD N 20 Sungaiselan.
Penelitian ini bertujuan untuk mengetahui gambaran kejadian karies gigi dan faktor-faktor yang berhubungan dengan kejadian karies gigi pada murid Sekolah Dasar Negeri 20 Sungaiselan Kabupaten Bangka Tengah tahun 2019. Data dan informasi yang dihasilkan diharapkan dapat dijadikan bahan rujukan dan referensi untuk menjadi bahan pertimbangan dalam pencegahan dan penaggulangan karies gigi.

\section{METODE PENELITIAN}

Penelitian ini merupakan penelitian deskriptif kualitatif dan pengumpulan data dengan menggunakan pendekatan cross sectional (Notoadmojo 2012). Penelitian dilaksanakan pada tanggal 15 September 2020 di SD Negeri 20 Sungaiselan Kabupaten Bangka Tengah.

Teknik pengambilan sampel yang digunakan pada penelitian ini adalah total sampling, yaitu pengambilan sampel berdasarkan jumlah seluruh populasi. Pada penelitian ini yang menjadi populasi penelitian adalah siswa kelas 2 SDN 20 Sungaselan. Pada saat pengambilan sampel sekolah menerapkan protokol kesehatan dengan menarapkan jumlah siswa yang datang hanya $50 \%$ dari seluruh jumlah keseluruhan siswa, sehingga dari 48 jumlah siswa kelas 2 yang datang pada saat pengambilan sampel hanya 24 orang. Siswa yang menjadi sampel pada penelitian ini berjumlah 24 orang.

Analisis data yang digunakan pada penelitian ini adalah analisis univariat yang meliputi tingkat konsumsi makanan kariogenik dan distribusi frekuensi menggosok gigi serta kejadian karies gigi pada anak sedangkan untuk analisa bivariat digunakan untuk menentukan hubungan antara variable tingkat konsumsi makanan kariogenik dengan kejadian karies gigi dan distribusi frekuensi menggosok gigi dengan kejadian karies gigi. Data yang didapatkan dikumpulkan dan dijadikan satu kemudian diolah mulai dari proses editing, coding pada setiap lembar jawaban responden, lalu mamasukkan dalam tabulating, kemudian data dianalisis menggunakan aplikasi SPSS (Hidaya \& Sinta 2018). Analisa berikutnya adalah menggunakan analisis Chi Square untuk mengetahui ada tidaknya hubungan antara variabel. Nilai uji signifikan pada penelitian dengan a sebesar $5 \%$. Hipoteisis diterima jika a $\leq$ 0,05 dan sebaliknya ditolah jika $a \geq 0,05$. 


\section{HASIL}

Berdasarkan penelitian yang telah dilakukan, didapatkan data karakteristik responden berdasarkan jenis kelamin. Data tersebut dapat dilihat dalam tabel 1.

Berdasarkan tabel 1 di atas diketahui bahwa yang menjadi objek penelitian berjumlah 24. Jumlah responden yang berjenis kelamin laki-laki adalah 13 anak $(54,17 \%)$ sedangkan responden yang berjenis kelamin perempuan berjumlah 11 anak $(45,83 \%)$.

Variabel yang digunakan pada penelitian ini meliputi uji statistic frekuencies yang meliputi tingkat konsumsi makanan kariogenik, distribusi frekuensi menggosok gigi. Adapun hasil yang didapatakan disajikan pada tabel 2 .

Berdasarkan tabel 2, diketahui bahwa siswa kelas 2 SD N 20 Sungaiselan memiliki tingkat konsumsi makanan kariogenik yang tinggi berjumlah 17 orang $(70,83 \%)$ sedangkan yang memiliki tingkat konsumsi makanan kariogenik rendah berjumlah 7 orang $(29,17 \%)$.

Berdasarkan data tabel 3 dapat diketahui bahwa murid yang hanya menggosok gigi kurang dari 2 kali sehari berjumlah 10 murid (33,33\%) sedangkan yang sudah menggosok gigi lebih dari dua kali berjumlah 14 murid $(66,67 \%)$.

Setelah dilakukan analisis univariat langkah selanjutnya adalah analisis bivariat untuk mengetahui hubungan antara jenis kelamin, tingkat konsumsi makanan kariogenik, dan frekuensi menyikat gigi terhadap kejadian karies gigi di SDN 20 Sungaiselan.

Berdasarkan hasil penelitian yang telah dilakukan diketahui murid laki-laki yang mengalami karies gigi berjumlah 9 siswa dan siswa perempuan yang mengalami karies gigi berjumlah 5 orang sedangkan untuk yang tidak mengalami karies gigi, para murid laki-laki sebanyak 4 siswa dan perempuan berjumlah 6 orang. Setelah data dianalisis dengan analisis Chi Square, didapati bahwa nilai $p=0,446$ yang lebih besar dari 0,05.

Berdasarkan hasil penelitian yang telah dilakukan diketahui bahwa Murid yang memiliki tingkat konsumsi makanan kariogenik tinggi memiliki frekuensi karies gigi sebasar 14 siswa, sedangkan yang tidak mengalami karies gigi yang memiliki tingkat konsumsi makanan kariogenik kategori tinggi berjumlah 3 orang dan berkategori rendah berjumlah 7. Setelah dilakukan analisis Chi Square, diketahui bahwa ni $p=$ 0, 001 yang lebih kecil dari 0,05.

Berdasarkan hasil penelitian yang telah dilakukan, diketahui bahwa Murid yang melakukan sikat gigi kurang dari 2 kali/hari dan mengalami karies gigi berjumlah 10 orang dan menyikat gigi lebih dari 2 kali berjumlah 4 orang sedangkan siswa yang tidak mengalami karies gigi pada frekensi menggosok gigi lebih dari 2 kali/hari berjumlah 10 orang. Berdasarkan analisis uji Chi Square diketahui bahwa nilai $p=$ 0,002 yang lebih kecil dari 0,05 .

\section{Pembahasan}

a. Hubungan antara jenis kelamin dengan kejadian karies gigi di SD Negeri 20 Sungaiselan

Berdasarkan hasil analisis Uji Chi Square yang telah dilakukan dapat disimpulkan bahwa tidak ada hubungan yang signifikan antara jenis kelamin dengan kejadian karies gigi di SD Negeri 20 Sungaiselan.

$\mathrm{Hal}$ ini tidak senada dengan hasil penelitian yang dilakukan oleh Hidaya dan Sinta (2018) yang menunjukkan bahwa anak perempuan memiliki resiko terkena karies gigi lebih tinggi dibandingkan dengan anak perempuan hal ini dikarenakan gigi anak perempuan lebih lama mengalami erupsi dibandingkan dengan anak laki-laki, sehingga gigi anak perempuan lebih rentan terkena karies gigi dibandingkan anak laki-laki, selain itu anak-anak perempuan lebih suka makanan yang manis sehingga menyebabkan anak perumpuan lebih banyak mengalami masalah karies. Selain karena proses erupsi, ada beberapa penyebab lain yang mempengaruhi seperti faktor hosr (gigi), substrat, ras, usia, vitamin, unsur saliva dan plak.

b. Hubungan antara tingkat konsumsi makanan kariogenik dengan kejadian karies gigi di SD Negeri 20 Sungaiselan

Berdasarkan hasil analisis Uji Chi Square yang telah dilakukan dapat disimpulkan bahwa tidak ada hubungan yang signifikan antara jenis kelamin dengan kejadian karies gigi di SD Negeri 20 Sungaiselan dapat disimpulkan bahwa ada hubungan yang signifikan antara tingkat konsumsi makanan kariogenik dengan kejadian karies gigi 
pada siswa SD Negri 20 Sungaiselan. Hasil penelitian ini senada dengan penelitian yang dilakukan oleh Maulida et al. (2014). Berdasarkan hasil analisis Chi Square yang dilakukan diperoleh hadil $\mathrm{p}=0,01 \quad(<0,05)$ yang menunjukkan adanya hubungan yang signifikan antara tingkat konsumsi makanan kariogenik dengan kejadian karies gigi.

Makanan kariogenik merupakan makanan yang manis dan lengket seperti biskuit, permen, manisan, eskrim dan minuman ringan (Nurhaliza, 2015). Maulani dan enterpise (2005) menyatakan bahwa Makanan yang mengandung karbohidrat atau pati, dan gula susahuntuk dibersihkan dari gigi yang akan berpotensi timbulnya lubang pada gigi. Mengkonsumsi makanan yang mengandung karbohidrat yang mudah terfermentasi terutama sukrosa yang berlebihan memiliki efek pada integritas dan kekuatan gigi seseorang. Mengkonsumsi karbohidrat kompelks seperti gandum relatif lebih tidak berbahaya karena tidak sempurna dihancurkan didalam mulut tetapi molokul karbohidrat yang rendah dengan mudah bersatu dengan plak dan dimetabolisme cepat oleh bakteri.

Dari hasil penelitian diketahui bahwa tingkat konsumsi makanan kariogenik berpengaruh terhadap kesehatan gigi seseorang. Semakin tinggi konsumsi terhadap makanan kariogenik maka akan semakin tinggi juga resiko anak untuk mengalami gigi berlobang serta akan memperparah tingkat karies gigi pada anak.

c. Hubungan antara frekuensi menyikat gigi dengan kejadian karies gigi di SD Negri 20 Sungaiselan

Berdasarkan hasil analisis Uji Chi Square yang telah dilakukan dapat disimpulkan bahwa tidak ada hubungan yang signifikan antara jenis kelamin dengan kejadian karies gigi di SD Negeri 20 Sungaiselan dapat disimpulkan bawa ada hubungan antara frekuensi menyikat gigi dengan kejadian karies gigi di SD N 20 Sungaiselan. Hal ini senada dengan penelitian yang telah dilakukan oleh Mukhbitin (2018) terhadap kejadian karies gigi pada anak kelas 3 di Ml AlMutmainnah pada uji chi square yang telah dilakukan diketahui bahwa ada hubungan yang signifikan antara frekuensi menggosok gigi dengan kejadian karies gigi. Selain itu Alim(2014 dalam Hidaya \& Sinta 2018) menyatakan bahwa ada hubungan antara menggosok gigi secara teratur dengan timbulnya status karies gigi pada anak sekolah.

Frekuensi yang baik untuk menyikat gigi minimal adalah 2 kali sehari yaitu setelah sarapan pagi dan sebelum tidur. Frekuensi gosok gigi yang tidak optimal dapat disebabkan karena anak tidak dibiasakan dan tidak tahu manfaat gosok gigi, sehingga anak tidak termotivasi dan tidak memiliki kesadaran untuk memelihara kesehatan gigi dan mulut. Keadaan tersebut akan memudahkan gigi terkena resiko penyakit gigi dan mulut (Sondang et al. 2018 ).

\section{KESIMPULAN}

Berdasarkan hasil penelitian diketahui bahwa dari 24 siswa kelas 2 SD Negeri 20 Sungaiselan didapat sebanyak 17 orang memiliki tingkat konsumsi makanan kariogenik tinggi dan 7 orang mengkonsumsi makanan kariogenik rendah sedangkan untuk distribusi frekuensi menggosok gigi diketahui bahwa sebanyak 10 orang melakukan sikat gigi kurang dari 2 kali sehari dan 14 anak melakukan sikat gigi lebih dari 2 kali sehari.

Hasil analisis Chi Square terhadap faktor jenis kelamin dan kejadian karies gigi didapati nilai $p=0,446 \quad(>0,05)$ hal inimenunjukkan tidak adanya hubungan jenis kelamin terhadap terjadinya karies gigi, pada analisis tingkat konsumsi makanan kariogenik dengan kejadian karies gigi didapati nilai $\mathrm{p}=0,001 \quad(<0,05)$ ada hubungan yang signifikan antara tingkat konsumsi makanan kariogenik dengan kejadian karies gigi sedangkan untuk hubungan antara frekuensi menggosok gigi dengan kejadian karies gigi didapati nilai $p=0,002(<0,05)$ sehingga didapati bahwa ada hubungan yang bermakna antara frekuensi menggosok gigi dengan kejadian karies gigi pada anak.

\section{Saran}

Karies gigi merupakan penyakit gigi yang mudah menyerang siapa saja, untuk itu perlu diperhatikan kesehatan gigi dan mulut kita seperti makanan kariogenik dan frekuensi menyikat gigi. 


\section{Ucapan terima kasih}

Alhamdulillah segala puji hanya milik Allah, SWT, atas rahmat dan karunia-Nya lah penulis dapat menyelesaikan jurnal ini dengan baik. Saya juga mengucapkan terimakasih kepada:

1. dr. Nur Muhammad Darussalam selaku Kepala Puskesmas Lampur

2. Kapala SD Negeri 20 Sungaiselan

3. Lidya, Am.Kep sebagai pengelola prgram UKS

4. Rebeka Rosmawati, SKM selaku promkes di Puskesmas Lampur Yang telah memberikan bimbingan dan masukan kepada penulis sehingga jurnal ini dapat diselesaikan.

\section{DAFTAR PUSTAKA}

Badan Penelitian dan Pengembangan Kesehatan. 2008. Laporan Hasil Riset Kesehatan Dasar Riskesdas Indonesia Tahun 2007. Jakarta: Kemkes RI. http://kesga.kemkes. go.id/images/pedoman/

Riskesdas\%202007\%20Nasional.pdf ((Diakses 14 September 2020).

Dinas kesehatan kabupaten bangka tengah. 2014. Profil kesehatan kabupaten Bangka Tengah tahun 2014. https://pusdatin.kemkes.go.id/ resources/download/profil/PROFIL K AB KOTA 2014/1904 Babel Kab B angka tengah 2014.pdf (Diakses 14 September 2020).
Hidaya N, Sinta MT. 2018. Gambaran Kejadian Karies Gigi Pada Anak Sekolah Dasar. Babul IImu Jurnal IImiah Muti Science Kesehatan , 9(1):69-79.

Kementerian kesehatan RI. 2019. Situasi Kesehatan Gigi dan Mulut 2019. https://www.kemkes.go.id/article/view /20030900005/situasi-kesehatangigi-dan-mulut-2019.(Diakses 14 September 2020).

Maulidani C dan Enterprice J. 2005. Kiat Merawat Gigi Anak. Yogyakarta: Elex Media Komputindo.

Mukhbitin F. 2018. Gambaran kejadian karies gigi pada siswa kelas $3 \mathrm{Ml} \mathrm{Al-}$ Mutmainnah. Jurnal Promkes 6(2) : 155-166.

Notoadmodjo S. 2012. Metodelogi penelitian. Jakarta : Rineka cipta.

Nurhaliza C. 2015. Karies Gigi. Jakarta :EGC

Pusdatin kemenkes. 2019. https://www. kemkes.go.id/download.php?file $=$ do wnload/pusdatin/infodatin/infodatin $\%$ 20gigi.pdf. (Diakses 14 September 2020)

Puskesmas Lampur. 2019. Profil Kesehatan Puskesmas Lampur. Bangka tengah: Data puskesmas lampur.

Sondang P dan Hamada T. 2008. Menuju Gigi dan Mulut Sehat. Medan: USU Press 
Tabel 1

Gambaran karakteristik subjek penelitian berdasarkan jenis kelamin murid kelas 2 SDN 20 Sungaiselan

\begin{tabular}{lll}
\hline $\begin{array}{l}\text { Jenis } \\
\text { Kelamin }\end{array}$ & Frekuensi & Persentase (\%) \\
\hline Laki-laki & 13 & 54,17 \\
Perempuan & 11 & 45,83 \\
\hline Total & $\mathbf{2 4}$ & $\mathbf{1 0 0}$ \\
\hline
\end{tabular}

\section{Tabel 2}

Distribusi tingkat konsumsi makanan karogenik pada siswa kelas 2 SD Negeri 20 Sungaiselan

\begin{tabular}{lcc}
\hline $\begin{array}{c}\text { Tingkat konsumsi } \\
\text { makananan } \\
\text { karogenik }\end{array}$ & Frekuensi & $\begin{array}{c}\text { Persentase } \\
(\%)\end{array}$ \\
\hline Tinggi & 17 & 70,83 \\
Rendah & 7 & 29,17 \\
\hline Total & $\mathbf{2 4}$ & $\mathbf{1 0 0}$ \\
\hline
\end{tabular}

Tabel 3

Distribusi frekuensi menggosok gigi siswa kelas 2 SD N 20 Sungaselan.

\begin{tabular}{ccl}
\hline Frekuensi menggosok gigi & Frekuensi & Persentase (\%) \\
\hline$<2$ kali/hari & 10 & 33,33 \\
$\geq 2$ kali/hari & 14 & 66,67 \\
\hline Total & 24 & 100 \\
\hline
\end{tabular}

Tabel 4

Hubungan antara jenis kelamin dengan kejadian karies gigi di SD Negeri 20 Sungaiselan

\begin{tabular}{|c|c|c|c|c|c|c|c|}
\hline \multirow{3}{*}{$\begin{array}{l}\text { Jenis } \\
\text { Kelamin }\end{array}$} & \multicolumn{4}{|c|}{$\begin{array}{c}\text { Angka Kejadian } \\
\text { Karies gigi }\end{array}$} & \multirow{2}{*}{\multicolumn{2}{|c|}{ Total }} & \multirow{3}{*}{$\begin{array}{c}\mathbf{P} \\
\text { Value }\end{array}$} \\
\hline & \multicolumn{2}{|c|}{$\begin{array}{c}\text { Karies } \\
\text { gigi }\end{array}$} & \multicolumn{2}{|c|}{$\begin{array}{c}\text { Tidak } \\
\text { Karies gigi }\end{array}$} & & & \\
\hline & $f$ & $\%$ & $f$ & $\%$ & $\sum$ & $\%$ & \\
\hline Laki-laki & 9 & $\begin{array}{l}37, \\
5\end{array}$ & 4 & $\begin{array}{l}16, \\
7\end{array}$ & $\begin{array}{l}1 \\
3\end{array}$ & $\begin{array}{l}54, \\
2\end{array}$ & 0,446 \\
\hline $\begin{array}{l}\text { Perempu } \\
\text { an }\end{array}$ & 5 & $\begin{array}{l}20 \\
8\end{array}$ & 6 & 25 & $\begin{array}{l}1 \\
1\end{array}$ & $\begin{array}{l}45 \\
8\end{array}$ & \\
\hline Total & $\begin{array}{l}1 \\
4\end{array}$ & $\begin{array}{l}58 \\
3\end{array}$ & 10 & $\begin{array}{l}41 \\
7\end{array}$ & $\begin{array}{l}2 \\
4\end{array}$ & 100 & \\
\hline
\end{tabular}

Tabel 5

Hubungan antara tingkat konsumsi makanan karogenik dengan kejadian karies gigi di SD Negeri 20 Sungaiselan

\begin{tabular}{|c|c|c|c|c|}
\hline \multirow{3}{*}{$\begin{array}{c}\text { Tingkat } \\
\text { konsumsi } \\
\text { makananan } \\
\text { kariogenik }\end{array}$} & \multicolumn{2}{|c|}{$\begin{array}{c}\text { Angka Kejadian } \\
\text { Karies gigi }\end{array}$} & \multirow{2}{*}{ Total } & \multirow{3}{*}{ P Value } \\
\hline & $\begin{array}{l}\text { Karies } \\
\text { gigi }\end{array}$ & $\begin{array}{l}\text { Tidak } \\
\text { Karies gigi }\end{array}$ & & \\
\hline & $\%$ & $\%$ & $\%$ & \\
\hline
\end{tabular}




\begin{tabular}{llllllll}
\hline Tinggi & 14 & 58,3 & 3 & 12,5 & 17 & 70,8 & 0,001 \\
Rendah & 0 & 0 & 7 & 29,2 & 7 & 29,2 & \\
\hline Total & 14 & 58,3 & 10 & 41,7 & 14 & 100 & \\
\hline
\end{tabular}

\section{Tabel 6}

Hubungan antara Frekuensi menyikat gigi dengan kejadian karies gigi di SD Negeri 20 Sungaiselan

\begin{tabular}{|c|c|c|c|c|c|c|c|}
\hline \multirow{3}{*}{$\begin{array}{l}\text { frekuensi } \\
\text { menggosok } \\
\text { gigi }\end{array}$} & \multicolumn{4}{|c|}{$\begin{array}{c}\text { Angka Kejadian Karies } \\
\text { gigi }\end{array}$} & \multirow{2}{*}{\multicolumn{2}{|c|}{ Total }} & \multirow{3}{*}{$\begin{array}{c}\mathrm{P} \\
\text { Value }\end{array}$} \\
\hline & \multicolumn{2}{|c|}{$\begin{array}{l}\text { Karies } \\
\text { gigi }\end{array}$} & \multicolumn{2}{|c|}{$\begin{array}{l}\text { Tidak } \\
\text { Karies gigi }\end{array}$} & & & \\
\hline & $f$ & $\%$ & $f$ & $\%$ & $\Sigma$ & $\%$ & \\
\hline$<2$ kali/hari & 10 & 41,7 & 0 & 0 & 10 & 41,7 & 0,002 \\
\hline$\geq 2$ kali/hari & 4 & 16,7 & 10 & 41,7 & 14 & 58,3 & \\
\hline Total & 14 & 58,3 & 10 & 41,7 & 24 & 100 & \\
\hline
\end{tabular}

